\title{
Master of Science in medical leadership and management and its role in the current NHS
}

\author{
Shaney Barratt, Kathryn Bateman and John Harvey
}

\begin{abstract}
Traditionally there has been little formal leadership and management education in the core medical curriculum. The Department of Health has recently emphasised the development of clinical leadership within the NHS. In this article, trainees share their experience of the Master of Science in medical leadership and management postgraduate qualification.
\end{abstract}

KEY WORDS: clinical leadership, management, Master of Science, medical leadership, postgraduate qualification

\section{Medical leadership within the NHS}

Effective leadership is increasingly important to all doctors within the NHS. Clinical leadership is not only important as part of individual continued professional development but it allows the involvement of doctors in the care and provision of services, now and in the future. With increasing pressure to improve efficiency in the NHS, change is seemingly a constant feature in today's NHS. Doctors often feel aggrieved at their perceived lack of involvement, particularly if the new directives seem to interfere with core values held by the profession (Box 1). ${ }^{1}$ Clinicians may feel that NHS managers and politicians have a different agenda to their clinical values - the socalled 'ethos gap'. ${ }^{1}$ Doctors are well placed to help bridge this divide and shape the future of the NHS but should be encouraged to develop the practical and theoretical leadership skills to best utilise their expertise and influence.

Lord Darzi's report, High quality care for all, placed a new emphasis on leadership from the frontline, highlighting bold plans for developing clinical leadership within the NHS. ${ }^{2}$ Clinicians are encouraged to take responsibility in fostering innovative practice, develop new services and address poor performance within their NHS organisation.

Subsequently, the Medical Leadership Competency Framework, jointly developed by the Academy of Medical Royal Colleges and the NHS Institute for Innovation and Improvement, outlined core leadership competencies considered essential to all doctors. ${ }^{3}$ It is intended that these competencies are integrated into each specialty curriculum (Box 2).

Traditionally, there has been little formal leadership and management education as part of the core medical curriculum; for

Shaney Barratt, respiratory registrar; Kathryn Bateman, respiratory registrar; John Harvey, consultant respiratory physician

North Bristol Lung Centre, Southmead Hospital, Bristol most junior doctors this involves a short management course in the later years of the specialist training programme, with limited 'on the job' experience. In recent years, there has been an increased interest in extended programmes, as either workbased learning or as qualifications, such as the Master of Science (MSc) in medical leadership (or clinical leadership), which aim to provide the knowledge, tools and practical leadership and management experience required to contribute fully to the modern NHS. ${ }^{4}$

The authors are currently undertaking an MSc in medical leadership and have provided an overview of their experiences.

\section{What is the MSc in medical leadership?}

The MSc in medical leadership is a university-affiliated postgraduate qualification. The majority of universities offer the option to achieve a postgraduate certificate, postgraduate diploma or master's degree. The course provides an opportunity to study the background academic knowledge of leadership and management theory and its application in practice. Students are encouraged to use this theory to critically reflect on their own approach to leadership to develop their own competency and confidence. Table 1 provides information on some of the courses available in the UK.

Box 1. General Medical Council's principles for good medical practice.

Examples of the 'duties of a doctor':

Make the care of your patient your first concern

Treat every patient politely and considerately

Respect patients' dignity and privacy

Listen to patients and respect their views

Keep your professional knowledge and skills up to date

Be honest and trustworthy

Work with colleagues in ways that best serve your patients' interests

Box 2. Core competencies of the Medical Leadership Competency Framework.

Demonstrating personal qualities

Improving services

Setting direction

Managing services

Working with others 


\section{Entry requirements}

The majority of courses are aimed at any healthcare professional that has leadership or management responsibilities, although a minority has a specific entry requirement for senior clinician/consultant level. A formal leadership or management position is not necessary to benefit from this course.

\section{Course format}

The majority of courses are structured in a part-time modular format, with the opportunity to study for one (postgraduate certificate level), two (diploma level) or three years (full masters qualification). The postgraduate certificate qualification requires attendance at tutored sessions at the university in two- or threeday blocks approximately four times per year. Flexibility to attend these sessions is therefore required from an employer. In addition a written assignment is attached to each module. Most assignments are short essays varying from 1,500-5,000 words and require considerable background reading.

The modules covered by each university vary but follow broad themes of leading and managing people, finance, human resource development, innovation and creative thinking, project management, strategic leadership, coaching and mentoring. For those wishing to proceed to the diploma phase, there is a similar modular format, followed by a 12-month organisational-based dissertation at master's level. The majority of universities offer an online resource developed for part-time students to liaise with others, to contact tutors, and to provide course and reading material.

\section{How much does the MSc cost?}

There is considerable variation in quoted course fees; from $\mathfrak{E} 6,500$ to $\mathfrak{2} 25,000$ for the full masters qualification. Some deaneries or strategic health authorities offer bursaries for postgraduate qualifications for doctors in training.

\section{Is it worthwhile?}

Absolutely. Leadership and management are crucial concepts in the constantly changing, complex environment of the NHS and doctors are regularly faced with related challenges. The course provides an academic theory-based framework into which healthcare professionals can integrate their experience. The knowledge of leadership theory gained through taught sessions, background reading and assignments develops critical thinking skills, an understanding of topics and concepts to relevant

Table 1. A list of some of the university-affiliated courses available in the UK.

\begin{tabular}{|c|c|c|c|c|c|c|}
\hline University & Degree & $\begin{array}{l}\text { Pg Dip or Pg } \\
\text { Cert options }\end{array}$ & $\begin{array}{l}\text { Prior management } \\
\text { experience required }\end{array}$ & $\begin{array}{l}\text { Modular and } \\
\text { part time }\end{array}$ & Intake & Contact \\
\hline Bangor & $\begin{array}{l}\text { MSc health and } \\
\text { social care leadership }\end{array}$ & Yes & Not specifically & Yes & Oct & hss601@bangor.ac.uk \\
\hline Bradford & $\begin{array}{l}\text { MSc leadership, } \\
\text { management and } \\
\text { change in health and } \\
\text { social care }\end{array}$ & Pg Dip only & $\begin{array}{l}\text { Two years' work } \\
\text { experience in public } \\
\text { service }\end{array}$ & Yes & Sept & $\begin{array}{l}\text { soh-recruitment@ } \\
\text { bradford.ac.uk }\end{array}$ \\
\hline $\begin{array}{l}\text { Bristol University } \\
\text { of the West of } \\
\text { England }\end{array}$ & $\begin{array}{l}\text { MSc in leadership and } \\
\text { management in health } \\
\text { and social care }\end{array}$ & Yes & $\begin{array}{l}\text { Two years in role with } \\
\text { management/leadership } \\
\text { responsibility }\end{array}$ & Yes & Sept & bbs.info@uwe.ac.uk \\
\hline Glasgow & $\begin{array}{l}\text { MSc in clinical } \\
\text { leadership }\end{array}$ & No & Not specifically & $\begin{array}{l}\text { Yes Fri and Sat } \\
\text { every } 4-6 \text { weeks } \\
\text { for } 2 \text { years }\end{array}$ & NA & $\begin{array}{l}\text { w.brian.howieson } \\
\text { @rcpsg.ac.uk }\end{array}$ \\
\hline Northampton & $\begin{array}{l}\text { MSc in leadership in } \\
\text { health and social care }\end{array}$ & Yes & $\begin{array}{l}\text { Experience in role } \\
\text { with management/ } \\
\text { leadership responsibility }\end{array}$ & Yes & $\begin{array}{l}\text { Entry } \\
\text { throughout } \\
\text { year }\end{array}$ & trevor@altstrat.co.uk \\
\hline Sheffield Hallam & $\begin{array}{l}\text { MSc in health and } \\
\text { social care leadership }\end{array}$ & Yes & Not specifically & Yes & NA & $\begin{array}{l}\text { pep-enquiries } \\
@ \text { @hu.ac.uk }\end{array}$ \\
\hline $\begin{array}{l}\text { Birkbeck College } \\
\text { and University of } \\
\text { London in } \\
\text { collaboration with } \\
\text { the RCP }\end{array}$ & $\begin{array}{l}\text { MSc in medical } \\
\text { leadership }\end{array}$ & Yes & $\begin{array}{l}\text { Minimum of } 1-2 \\
\text { years in specialty } \\
\text { training }\end{array}$ & Yes & Oct & $\begin{array}{l}\text { education-courses } \\
@ \text { @rcplondon.ac.uk }\end{array}$ \\
\hline Warwick & $\begin{array}{l}\text { MSc in medical } \\
\text { leadership }\end{array}$ & $\begin{array}{l}\text { No - full } \\
\text { MSc only }\end{array}$ & $\begin{array}{l}\text { Aimed at consultants } \\
\text { and GPs with at least } \\
\text { two years' experience }\end{array}$ & Yes & $\begin{array}{l}\text { Jan } \\
\text { or Feb }\end{array}$ & $\begin{array}{l}\text { r.g.palmer } \\
@ \text { @arwick.ac.uk }\end{array}$ \\
\hline
\end{tabular}

GPs = general practitioners; MSc $=$ Master of Science; Pg Cert = postgraduate certificate; Pg Dip = postgraduate diploma; RCP = Royal College of Physicians 
leadership and management and encourages reflection of what effective leadership entails. This is integrated with the practical tools to improve the ability to lead and to enable a genuine dialogue with NHS managers. In the current environment it is increasingly likely that formal experience in leadership will be actively sought. This qualification provides evidence of this and highlights a trainee's ability and enthusiasm to learn.

\section{References}

1 Pendleton D, King J. Values and Leadership. BMJ 2002;325:1352-5.

2 Department of Health. High quality care for all: NHS next stage review final report. London: DH, 2008.
3 NHS Institute for Innovation and Improvement. Medical leadership competency framework. London: NHSIII, 2008. www.institute.nhs.uk/assessment_tool/general/medical_leadership_ competency_framework_-_homepage.html

4 Cawley D. Management circuit training. BMJ Careers September 2009.

Address for correspondence: Dr S Barratt, North Bristol Lung Centre, Southmead Hospital, Westbury-on-Trym, Bristol BS10 5NB. Email: shaneybarratt@hotmail.com

\section{NCC-CC GUIDELINES}

\section{Type 2 Diabetes}

\section{National clinical guideline for management in primary and secondary care (update)}

Type 2 diabetes can cause severe complications, affecting the eye, the nervous system and the kidney. The overall risk of cardiovascular disease is more than doubled, and life expectancy is reduced by an average seven years. In 2002, the National Institute for Health and Clinical Excellence (NICE) published a suite of five guidelines dealing with different aspects of the care of type 2 diabetes. The rising prevalence of the disease, and the range of complications which can arise, reinforce the importance of up-to-date guidance and accordingly NICE have asked the NCC-CC to produce this guideline, amalgamating and updating the previously published work.

Topics of particular relevance to life expectancy, such as control of cholesterol and lipid levels, and management of hypertension, are covered in the guideline. It deals with major complications such as renal disease. There are also key recommendations in areas of great importance to patients such as structured education and the monitoring of glucose levels. Naturally, there are also sections dealing with control of blood glucose levels and the use of the various drugs available for this purpose.

The guideline is an invaluable resource for general physicians, diabetologists, dieticians, general practitioners, nurses and healthcare professionals who are involved in the management and care of people with type 2 diabetes.

The challenge now is to implement its recommendations and to make a genuine difference to the well-being and health of those with type 2 diabetes.

\section{Contents}

The development - Introduction - Methodology - Key messages of the guideline The guideline • Education • Lifestyle management/non-pharmacological management - Glucose control levels • Self-monitoring of plasma glucose • Oral glucose control therapies - Glucose control: insulin therapy • Blood pressure therapy • Cardiovascular risk estimation - Management of blood lipid levels • Anti-thrombotic therapy - Kidney damage

- Eye damage - Nerve damage - Areas for future research

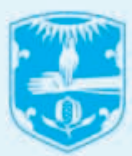
Royal College of Physicians setting higher medical standards

The National Collaborating Centre for Chronic Conditions

This guideline is part of a series commissioned by NICE which aims to ensure that standards of care throughout England and Wales are uniformly high.

Developed by the National Collaborating Centre for Chronic Conditions at the Royal College of Physicians

Published MAY 2008

ISBN: 9781860163333

Price: $£ 33.00$ UK, $£ 36.00$ overseas (prices include postage and packing) $10 \%$ discount on all RCP publications to fellows and members

Please quote the reference Clinical Medicine when making your order 